University of Nebraska - Lincoln

DigitalCommons@University of Nebraska - Lincoln

Faculty Publications, Department of Psychology

Psychology, Department of

2008

Stress and Eyewitness Memory

Ani A. Aharonian

Brian H. Bornstein

University of Nebraska-Lincoln, bbornstein2@unl.edu

Follow this and additional works at: https://digitalcommons.unl.edu/psychfacpub

Part of the Psychiatry and Psychology Commons, and the Psychology Commons

Aharonian, Ani A. and Bornstein, Brian H., "Stress and Eyewitness Memory" (2008). Faculty Publications, Department of Psychology. 485.

https://digitalcommons.unl.edu/psychfacpub/485

This Article is brought to you for free and open access by the Psychology, Department of at DigitalCommons@University of Nebraska - Lincoln. It has been accepted for inclusion in Faculty Publications, Department of Psychology by an authorized administrator of DigitalCommons@University of Nebraska - Lincoln. 
Published in Encyclopedia of Psychology and Law, ed. Brian L. Cutler (Newbury Park, CA: SAGE Publications, 2008).

Copyright $\odot 2007$ SAGE Publications. Used by permission.

http://www.sage-ereference.com/psychologylaw/Article n312.html

\title{
Stress and Eyewitness Memory
}

\author{
Ani A. Aharonian and Brian H. Bornstein
}

\begin{abstract}
Stress exerts complex effects on eyewitness memory. On the whole, it has a negative effect, but this can be quite variable depending on the level of stress and the aspect of the witnessed event that one is trying to remember. Stress operates similarly in affecting person recognition (i.e., lineup performance) and recall of event details.
\end{abstract}

The effects of stress on eyewitness memory and identification are of interest because of the fact that persons witnessing a crime, especially a violent crime, commonly (though not always) experience stress. "Stress" is itself a rather vague term that has been interpreted differently by various commentators, but generally, it can be taken to denote a negative emotional state associated with both physiological changes and a subjective set of cognitions. The physiological experience of stress is associated with increased arousal, marked by increases in heart rate, blood pressure, and muscle tone. The subjective experience typically includes some perception of threat and feelings of anxiety.

People often assume that a high level of emotion, positive or negative, will facilitate memory; however, it is also possible that intense emotion, especially the high level of stress associated with witnessing a crime, would lead to decrements in memory for details of the crime itself and for the ability to recognize the persons involved. Early studies investigating the effects of stress on memory yielded inconsistent findings. Some researchers found that accuracy suffered when witnesses were under stress, others found that it was unaffected, and a minority of researchers reported improvements in accuracy. This ambiguity can be explained, in part, by variations in the degree of stress. The Yerkes-Dodson law proposes that the relationship between arousal and performance can be plotted as an inverted $U$, where with moderate increases in arousal, performance is improved but with too much arousal performance declines. This theory was subscribed to by many researchers, and ini- tially, it was thought to provide an explanation for the seemingly contradictory pattern of research findings. The studies that found improvements may have elicited an optimal level of stress or arousal, whereas those studies that had found decrements had exceeded that optimal level of stress. However, this explanation proved inadequate as the body of research grew because of the difficulty in comparing degrees of stress and also because of findings indicating that stress is not a unidimensional construct, as proposed by the Yerkes-Dodson law, but instead has multiple components (e.g., physiological, affective, cognitive, behavioral, etc.).

An alternative explanation is that with higher levels of emotional stress, the observer's attention becomes narrower and more focused. As a result, memory for central and closely attended-to details improves, while memory for more peripheral details declines. This distinction between central and peripheral details also helps explain some of the inconsistent findings, where stress sometimes helps but at other times impairs memory.

Research reviews and meta-analyses of the topic reveal that, taken as a whole, stress has more of a negative than a positive impact on eyewitness memory in terms of both identification of the perpetrator and recall of event details. Eyewitnesses in highstress situations are less likely to be able to correctly identify a perpetrator from a lineup, and recall of details associated with the witnessed crime is less likely to be accurate. The type of lineup administered and the type of recall appear to moderate the effect of stress on accuracy. High-stress situations disproportionately affect eyewitness identifi- 
cation accuracy, such that the likelihood of an accurate identification is reduced when the target person (i.e., perpetrator) is present in the lineup, but the effect on target-absent lineups is negligible. In other words, when the target person is present in the lineup, witnesses are more likely to select someone other than the target (i.e., a foil-namely, an innocent person in a police lineup) or incorrectly report that the target is not present in the lineup, thus rejecting the lineup. In contrast, when the target is absent, the likelihood that a witness will correctly reject the lineup is virtually unaffected.

In eyewitness studies, witnesses are typically asked to report information in one of two ways: narrative or interrogative. With narrative or free recall, witnesses are asked to report what they recall and can choose what information to report. The interrogative type of recall requires a witness to answer specific questions about various details of the witnessed event. Highstress situations produce a greater decline in accuracy for interrogative recall than for narrative recall. One possible explanation for this difference is that with narrative recall, witnesses are free to choose what information to report and may opt not to report details of which they are not certain.

These findings extend partly to children as well. Child eyewitnesses perform worse when under stress, but it is unclear whether stress has a disproportionately negative effect on children. Stress effects can also be complicated by the presence of a particularly arousing, eye-catching aspect of the event, such as gore or a weapon. Research on stress and memory also suffers from methodological complications. There are limits to the amount of stress that one can ethically induce in an experimental situation, and even with highly arous- ing materials, research participants are usually not personally threatened by the witnessed event; that is, they are bystanders rather than victims or potential victims, which is likely to influence not only their stress level but also their behavior, degree of attention, and so forth. Some innovative research designs have attempted to overcome this limitation by studying victims/witnesses of real crimes or individuals undergoing stressful medical procedures.

In conclusion, it is hard to generalize about the effects of stress on eyewitness memory. The findings are somewhat mixed, and the explanation for stress effects on memory is far from clear, making generalization difficult. More research is necessary to resolve this uncertainty. However, it is clear that, overall, high levels of stress harm eyewitness memory in more ways than they help it.

\section{Further Readings}

Deffenbacher, K. A., Bornstein, B. H., Penrod, S. D., and McGorty, E. K. A meta-analytic review of the effects of high stress on eyewitness memory. Law and Human Behavior vol. 28 (2004). pp. 687-706

Peters, D. P. (1997). Stress, arousal, and children's eyewitness memory. In N. L. Stein, ed., P. A. Ornstein, ed., B. Tversky, ed., \& C. Brainerd (Eds.), Memory for everyday and emotional events, pp. 351-370. Mahwah, NJ: Lawrence Erlbaum.

Reisberg, D., \& Heuer, F. (2006). The influence of emotion on memory in forensic settings. In M. Toglia, J. D. Read, D. F. Ross, \& R. C. L. Lindsay (eds.), Handbook of eyewitness psychology: Vol. 1. Memory for events, pp. 81-116. Mahwah, NJ: Lawrence Erlbaum. 